\title{
EFFECTS OF NON-TOXIC FILAMENTOUS CYANOBACTERIA ISOLATED FROM TRI AN RESERVOIR ON Daphnia
}

\author{
Pham Thanh Luu ${ }^{1,2, *}$, Tran Thi Hoang Yen², Tran Thanh Thai ${ }^{2}$, Ngo Xuan Quang ${ }^{1,2}$ \\ ${ }^{1}$ Graduate University of Science and Technology, VAST, Vietnam \\ ${ }^{2}$ Institute of Tropical Biology, VAST, Vietnam
}

Received 27 June 2019 accepted 28 July 2020

\begin{abstract}
This study is aimed to examine whether the presence of non-toxic filamentous cyanobacteria can cause toxic effects on Daphnia magna. Six strains of Oscillatoria perornata were isolated from the Tri An Reservoir and cultured in our laboratory for investigation. The results revealed that all strains were negative with the $m c y A$ moleculer marker. The high performance liquid chromatography (HPLC) results showed that toxin was not detected in their culture products, indicating that these strains corresponded to non-toxin producing strains. However, the results of chronic assay indicated that these non-toxin producing $O$. perornata conferred toxic effects on the tested animals. The age at first reproduction of $D$. magna was delayed and the survival of $D$. manga decreased in proportional with the increase of the density of cells of $O$. perornata exposed. Significant differences in the life history responses were observed for $D$. mangna exposed to $O$. perornata. These results suggested that bioactive secondary metabolites other than microcystins produced by the filamentous cyanobacteria $O$. perornata may contribute to the toxic effects on Daphnia. Besides cyanotoxins, other secondary metabolites must be taken into account when investigating the toxic effects of cyanobacteria.
\end{abstract}

Keywords: Oscillatoria perornata, chronic toxic effect, cyanobacterial crude extract, microcystin.

Citation: Pham Thanh Luu, Tran Thi Hoang Yen, Tran Thanh Thai, Ngo Xuan Quang, 2020. Effects of non-toxic filamentous cyanobacteria isolated from Tri An Reservoir on Daphia. Academia Journal of Biology, 42(3): 43-52. https://doi.org/10.15625/2615-9023/v42n3.13900.

*Corresponding author email: thanhluupham@gmail.com

(C2020 Vietnam Academy of Science and Technology (VAST) 


\section{INTRODUCTION}

The increase of human activities along with deficient water management have led to the enhancement of eutrophication in inland waters used for recreational purposes and as drinking water sources (Pham \& Utsumi, 2018). Water eutrophication characterized by high nutrient inputs (particularly nitrogen and phosphorus species) has enhanced the development of cyanobacteria in lakes and reservoirs, leading to formation of surface blooms that may accumulate as scum. The occurrence of cyanobacterial blooms (CYB) is becoming more frequent worldwide. CYBs have been reported in at least 108 countries and territories worldwide except Antarctica (Harke et al., 2016).

In freshwaters worldwide, the occurrence of CYBs are mainly caused by colonial Microcystis spp., filamentous Planktothrix/Oscillatoria spp. and Anabaena spp. (Figueiredo et al., 2004). These species are well-known to produce several secondary metabolite toxins such as microcystins, anatoxins and saxitoxins. However, blooms of cyanobacteria usually consist of toxic and nontoxic strains/species that cannot be distinguished by morphological observation methods because many strains of cyanobacteria appear to be identical under a microscope (Kardinaal et al., 2007; Pham et al., 2015). The detection of the presence of the $m c y$ gene cluster has been widely used as means for distinguishing toxic and non-toxic genotypes in both environmental samples and axenic cultures.

In Vietnam, several studies have focused on morphological characterization and microcystin (MC) production for the identification of cyanobacteria species (Nguyen et al., 2007; Dao et al., 2010; Pham \& Dang, 2019). The most commonly reported species is the colonial Microcystis aeruginosa, which have been reported from lake Thanh Cong, Huong River, Nui Coc, Tri An and Dau Tieng Reservoirs. Other studies have been recently reported the presence of toxins from Vietnam's waters (Dao et al., 2010; Duong et al., 2014; Pham et al., 2017).
The colonial Microcystis (M. aeruginosa, $M$. botrys, $M$. wesenbergii) and filamentous Oscillatoria (O. agardhii, $O$. isothrix, $O$. rubescens, $O$. zahidii) from freshwater in Vietnam have been reported to be toxic on aquatic plants and animals (Nguyen et al., 2007; Dang Dinh Kim et al., 2014; Dao et al., 2016).

In lake ecosystems, microcrustacean Daphnia is a filter-feeder, and can consumes planktonic cyanobacteria. These filter feeders are, therefore, seriously affected by the presence of toxic and nontoxic cyanobacteria presence in the water column (Dao et al., 2010). The toxic effects of cyanobacteria on Daphnia have been extensively investigated (Ferrão-Filho \& Kozlowsky-Suzuki 2011; Herrera et al., 2015). Acute toxic effects of cyanobacteria on Daphnia including inhibition of filtration rate, decrease in swimming movements, and even death (Ferrão-Filho et al., 2009; Smutná et al., 2014). As for the chronic effects, decrease of fecundity and population growth rate have been reported (Dao et al., 2010; Herrera et al., 2015). However, previous studies have mainly focused on the cyanobacterium Microcystis, but little attention has been paied for the interaction between zooplankton and filamentous cyanobacteria.

The filamentous cyanobacteria Ocillatoria distribute widely in many lakes, rivers and reservoirs worldwide. However, little is known about their toxicity in the aquatic environment. In this study, we isolated several strains of the Ocillatoria from the Tri An Reservoirs and maintained in the laboratory condition. Microscopic observation was used for morphological identification. The ability to produce cyanotoxins was examined with the $m c y A$ gene fragment, and toxins concentration in culture was detected by high performance liquid chromatography (HPLC). The chronic toxic effects of non-toxic strains of Oscillatoria spp. on the freshwater Daphnia magna were investigated. 


\section{MATERIALS AND METHODS}

\section{Sample collection and isolation}

Cyanobacteria samples were collected from the Tri An Reservoir between February and August of 2017 using a plankton net of 25 micron mesh size. In the laboratory, samples were observed under a microscope and three dominant groups including Microcystis, Oscillatoria and Anabaena were identified in the samples. Living and Lugol-fixed cyanobacterial samples were used for observation. Several single cyanobacterial trichomes of Oscillatoria spp. from living samples were isolated by micropipetting, washed, and cultured in Z8 medium (Pham et al., 2015). These cultures were grown at $28^{\circ} \mathrm{C}$ under light conditions 12 hours: 12 hours (light:dark cycle) provided by 40-W fluorescent lamps, which generated an approximate luminous intensity of $50 \mu \mathrm{mol}$ photons $/ \mathrm{m}^{2} / \mathrm{s}$. Cultured biomass was collected at stationary phase for microcystins analysis according to the methods reported previously by Pham et al. (2015).

\section{DNA extraction}

Total genomic DNA was extracted from the culture following the methods of Hisbergues et al. (2003) with minor modifications. Briefly, $2 \mathrm{~mL}$ of cultures were centrifuged and suspended in TE buffer (50 $\mathrm{mM}$ Tris/HCl, $40 \mathrm{mM}$ EDTA, $\mathrm{pH}$ 8.0). An aliquot of $30 \mu \mathrm{L}$ of $10 \%$ SDS (sodium dodecyl sulfate) and proteinase $\mathrm{K}$ (final concentration: $100 \mu \mathrm{g} / \mathrm{mL}$ in $0.5 \%$ SDS) was then added and incubated for $60 \mathrm{~min}$ at $37^{\circ} \mathrm{C}$. Then, $5 \mathrm{M} \mathrm{NaCl}(100 \mu \mathrm{L})$ and $\mathrm{CTAB} / \mathrm{NaCl}$ solution $(10 \%$ CTAB in $0.7 \mathrm{M} \mathrm{NaCl})(80 \mu \mathrm{L})$ were added, and the samples were incubated for $10 \mathrm{~min}$ at $65^{\circ} \mathrm{C}$. DNA was then extracted twice with phenol:chloroform:isoamyl alcohol $(25: 24: 1 \mathrm{v} / \mathrm{v})$. After centrifugation for $5 \mathrm{~min}$ at $6.000 \times g$ at $4{ }^{\circ} \mathrm{C}$, the supernatant was collected and transferred to a fresh tube. The DNA was then rinsed with $1 \mathrm{~mL}$ of $70 \%$ ethanol and dried under vacuum. The final DNA sample was rehydrated in $20 \mu \mathrm{L}$ of $1 \times \mathrm{TE}$ buffer $(10 \mathrm{mM}$ Tris and $1 \mathrm{mM}$ EDTA [pH 8.0]).

\section{PCR amplification}

To detect the presence of cyanobacterial DNA, the primer pair of CYA-F/CYA-R was used to amplify a $1.200 \mathrm{bp}$ fragment of the 16s rDNA gene common to all cyanobacteria (Urbach et al., 1992). Microcystin is encoded by the microcystin synthetase (mcy) gene cluster that consists of 10 genes ( $m c y A$ to $m c y J)$. To detect the toxic strains, the microcystin synthetase region $m c y A$ (297 bp) in Oscillatoria, was amplified using the primer pair of mcyA-Cd1F/mcyA-Cd1R (Hisbergues et al. 2003). The mcyA gene is suitable for detection of MC-producing cells of the genera Anabaena, Microcystis, and Oscillatoria (Hisbergues et al. 2003). The MC-producing cyanobacterium $M$. aeruginosa NIES-102 obtained from NIES Collection (Tsukuba, Japan) was used for positive controls. For each sample, duplicate PCR reactions were conducted. PCR reactions were prepared in a volume of 20 $\mu \mathrm{L}$ containing $2 \mu \mathrm{L}$ of $10 \times$ Ex-Taq Buffer, $200 \mu \mathrm{M}$ of each dNTP, $0.5 \mu \mathrm{L}$ of each primer $(10 \mu \mathrm{M}), 0.5 \mathrm{U}$ of Ex-Taq polymerase and 20 ng of template DNA. Amplification was performed in a Thermal Cycler (Applied Biosystems, Foster City, California, USA) with the following condition: initial denaturation at $95^{\circ} \mathrm{C}$ for $5 \mathrm{~min}, 35$ cycles [94 ${ }^{\circ} \mathrm{C} / 1 \mathrm{~min}, 54{ }^{\circ} \mathrm{C} / 1 \mathrm{~min}, 72{ }^{\circ} \mathrm{C} / 1.5 \mathrm{~min}$ ] and a final extension step at $72{ }^{\circ} \mathrm{C}$ for 10 min. PCR products were examined on $1.5 \%$ (w/v) agarose gels stained with Safe-Red ${ }^{\mathrm{TM}}$ and photographed under UV light.

\section{Microcystins extraction and measurement}

The MC in cyanobacteria were first extracted in $4 \mathrm{~mL}$ of $100 \%$ methanol $(\mathrm{MeOH})$ and completed with the aid of sonication for 3 min and centrifugation at $1800 \times \mathrm{g}$ for $30 \mathrm{~min}$. The supernatant was dried at room temperature, re-dissolved in $0.5 \mathrm{~mL} \mathrm{MeOH}$ (100\%) and centrifuged at $4000 \mathrm{~g}$ for $5 \mathrm{~min}$. The sample was then passed through a Minisart RC4 filter membrane $(0.2 \mu \mathrm{m}$ pore size, Sartorius, Germany), and kept at (-)20 ${ }^{\circ} \mathrm{C}$ prior analysis. To analyse the MCs content, a reverse-phase HPLC with UV-visible photodiode array (PDA) detector (Dionex 
UltiMate 3000, Thermo Scientific, USA) was used. MCs were separated with a silica-based, reverse-phase $\mathrm{C} 18$ column $\left(\right.$ Acclaim $^{\mathrm{M}} 120$ C18 $5 \mu \mathrm{m}, 4.6 \times 150 \mathrm{~mm}$, USA) maintained at $40{ }^{\circ} \mathrm{C}$. The samples were carried with a mobile phase consisting of methanol: $0.05 \mathrm{M}$ phosphate buffer $(\mathrm{pH} 2.5 ; 50: 50 \mathrm{v} / \mathrm{v})$ at a flow rate of $0.65 \mathrm{~mL} / \mathrm{min}$. MC congeners were detected at $238 \mathrm{~nm}$ and identified on the basis of both their retention time and characteristic UV spectra. Three MCs (MC-LR, MC-RR, and MC-YR) purchased from Wako (Chuoku, Osaka, Japan), were used as standards. A detection limit of the HPLC system used is $0.12 \mu \mathrm{g} / \mathrm{L}$.

\section{Chronic toxicity assay}

Daphnia magna from the MicroBioTests Inc, Belgium, maintained under a laboratory condition of the Institute of Tropical Biology, Ho Chi Minh City, for several months was used for the test. They were maintained in ISO medium and fed with a mixture of green algae Chlorella sp. and Scenedesmus sp., which were cultivated in COMBO medium. Both Daphnia and green algae were maintained in the laboratory at $25 \pm 1^{\circ} \mathrm{C}$, with a $14 \mathrm{~h}: 10 \mathrm{~h}$ photoperiod (light: darkness).

Chronic toxicity assay was performed according to the Protocol 211 of the Organization for the Economical Cooperation and Development (OECD 2012) using $50 \mathrm{~mL}$ beaker cups containing $20 \mathrm{~mL}$ of ISO medium. Neonates of D. magna less than 24 hours-age were maintained individually in $50 \mathrm{~mL}$ beaker cups, and assigned to 3 different treatments with the density of 20 (treatment A), 50 (treatment B) and 100 (treatment $\mathrm{C}$ ) $\times 10^{3}$ cell $/ \mathrm{mL}$ of Oscillatoria spp. and a control (containing only ISO medium). Densities of Oscillatoria spp. were determined by counting of Lugol's fixed sub-samples taken from each exposure at the starting, 6, 12, 24 and 48 hours. All samples were counted using the Sedgewick Rafter counting chamber on an inverted microscope. Oscillatoria densities were estimated by determining the length of 50 filaments and then dividing the total length of filaments by the length of one cell $(4 \mu \mathrm{m})$
(Desikachary, 1959). The control D. magna were fed with green algae Chlorella sp. and Scenedesmus sp. Each treatment contained 15 replicates $(n=15)$. Test solutions and cyanobacteria were renewed every second day. Mortality, maturation and production of live offspring were recorded daily. Each mother daphnid was checked daily for the numbers of neonates per clutch. Reproduction was calculated as total accumulated offsprings reproduced by all mother daphnids in each treatment. Fecundity was defined as the average number of offsprings in one clutch reproduced by one mother daphnid. The chronic tests lasted for 15 days.

\section{Statictical analysis}

Data on mortality, maturation and production of live offsprings were presented as the mean \pm SD. The significant difference between the exposure and control treatment was tested using one-way analysis of variance (ANOVA). When the ANOVAs were significant, the pair wise comparison using Tukey's honestly significant difference (HSD) post-hoc test was used to determine significant difference between the exposure and the control treatments. $P$ values less than 0.05 were used for the significant difference.

\section{RESULTS AND DISCUSSION}

\section{Isolation and morphological characteristics}

In this study we aimed to investigate the toxicity of the filamentous cyanobacteria species Oscillatoria perornata. For this purpose, we selected and isolated several strains of this species. In total, 6 strains of Oscillatoria perornata have been successfully isolated from the Tri An Reservoir and maintained in cultures (Fig. 1). Oscillatoria is a common group of cyanobacteria in many lakes and rivers worldwide. In Vietnam, the presence of $O$. perornata has only been reported from Huong and Nhu Y Rivers (Nguyen et al., 2007), Tri An Reservoir and La Nga River (Luu \& Nguyen, 2008). Oscillatoria is a major proportion in the phytoplankton in ponds and reservoirs in Vietnam (Pham et al., 2017). 


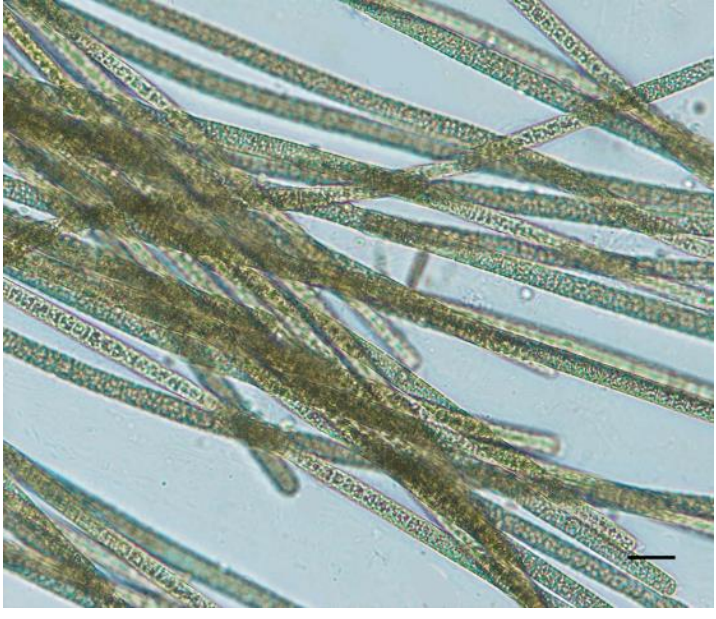

Figure 1. Morphological appearance of Oscillatoria perornata. Scale bar: $10 \mu \mathrm{m}$

Detection of microcystin synthetase genes and quantification of microcystins with HPLC

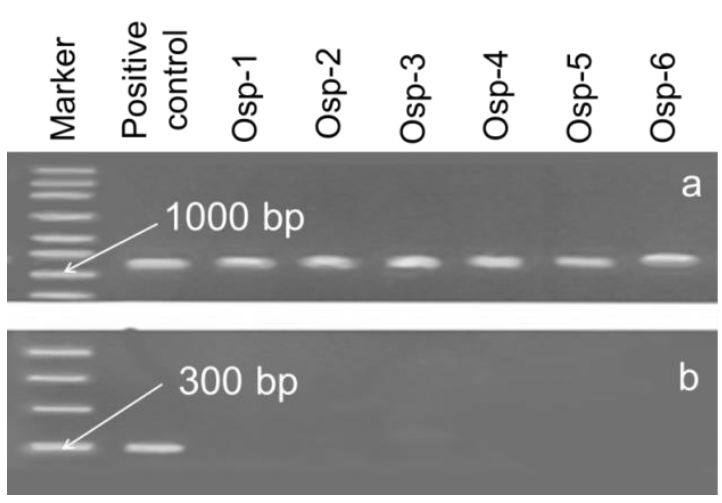

Figure 2. PCR products of agarose electrophoresis gels of (a) 16S rDNA amplification products, and (b) $m c y A$ amplification products. Marker: PHY Marker; Positive control: $M$. aeruginosa NIES-102;

Osp-1 to Osp-6 indicated 6 strains of $O$. perornata isolated from Tri An Reservoir

The presence of the cyanobacterial-16S rDNA fragment was examined for all strains of $O$. perornata. The results indicated that the $16 \mathrm{~S}$ rDNA fragments are presented in all strains confirming that all strains examined were cyanobacteria (Fig. 2a). The ability to produce MCs was examined by the presence of the mcyA gene. The results showed that the $m c y A$ fragment was not amplified in all isolated strains of $O$. perornata, indicating that these strains are the non-toxin producers (Fig. 2b). The HPLC results also indicated that toxin was not detected in these cultures (Fig. 3).

Till now, little is known about the toxicity of tropical cyanobacterial microflora, especially of Oscillatoria species. Most of the previous studies on toxicity and MCs production of cyanobacteria from Vietnam waters were only about Microcystis. Only few studies have been conducted on other cyanobacteria like Oscillatoria or Anabaena. Pham et al. (2015) isolated about 70 strains of cyanobacteria from Dau Tieng Reservoir and examined their microcystin producing ability. The strains examined were mainly Microcystis, Anabaena, Arthrospira and Cylindrospermopsis, but Oscillatoria were not included. Dao et al. (2010) also cultured several strains of Microcystis, Aphanizomenon, Anabaena and Cylindrospermopsis from Tri An Reservoir, but Oscillatoria species were not included. Although many species of Oscillatoria were presented in the Tri An Reservoir and also in the La Nga and Dong Nai Rivers, molecular analyses as well as toxicity of those Oscillatoria species have never been reported. In the present study, the ability of 6 strains of $O$. perornata to synthesize microcystins was examined, but none of them has the portion of $m c y A$ gene. These results are in agreement with the previous report that Microcystis species were the main toxin producing species in the Vietnamese waters.

Several strains of Oscillatoria are known to produce microcystin (Sivonen et al., 1990; Chorus \& Bartram, 1999). The most frequently reported is the ability of $O$. agardhii to produce demethylated microcystins (containing d-Asp and/or dehydroalanine). Brittain et al. (2000) reported a toxic $O$. tenuis, strain E6 with the ability to produce a fully methylated microcystin (MC-LR) and a new 1-homoarginine containing microcystins (MC- 
LHArg). From Vietnam water the ability of some strains of Oscillatoria or (Planktothrix) isolated from a fish pond in Soc Trang Province to produce toxin has been reported (Dao et al., 2016). Many filamentous cyanobacteria from urban lakes in Mexico were reported to produce microcystins
(Pineda-Mendoza et al., 2012). Probably, the ability of filamentous cyanobacteria from Vietnam waters to produce toxic compounds was underestimation. Future research on toxin producing ability of filamentous cyanobacteria genera/species from various habitats in Vietnam is recommended.

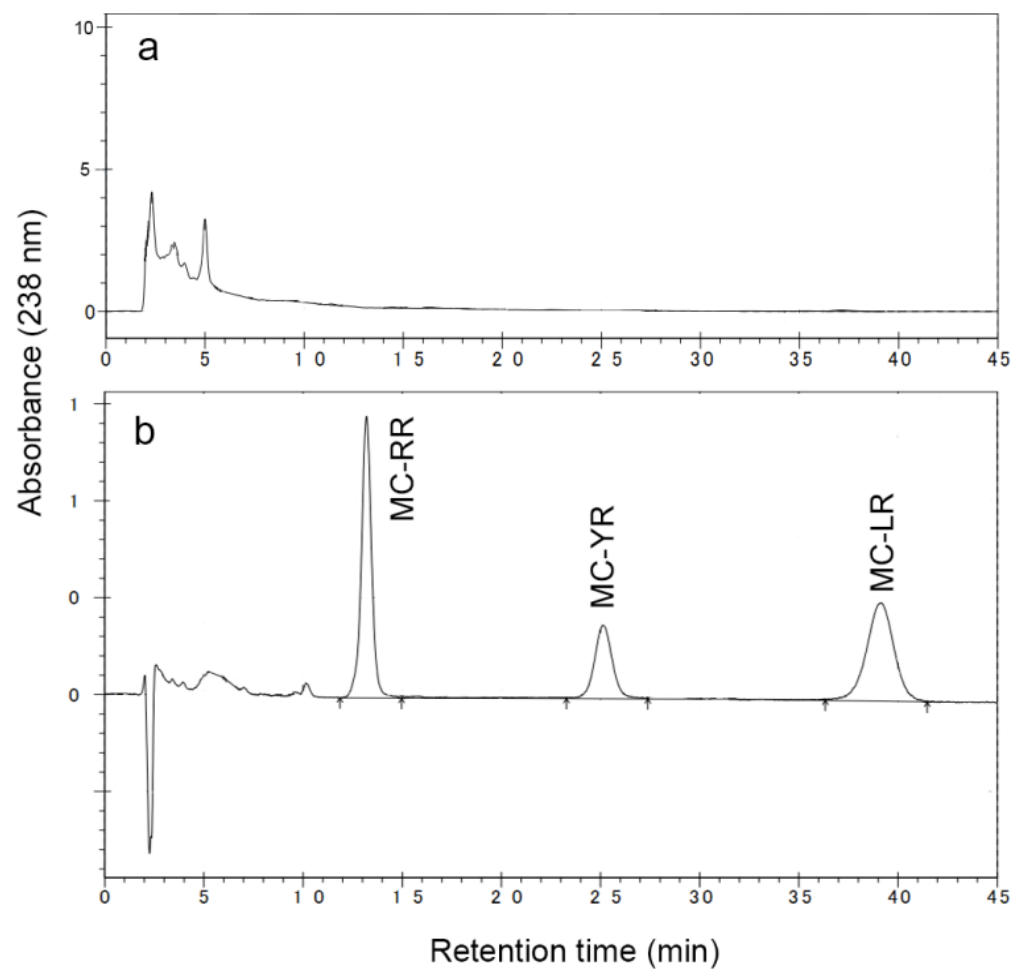

Figure 3. HPLC patterns of (a) Ocillatoria perornata and (b) microcystin standards

\section{Chronic toxicity of Ocillatoria perornata} on Daphnia magna

D. magna could grow well in the control condition with the mortality of less than $15 \%$ that meets well with the requirement for the chronic test. The chronic effects of $O$. perornata on the survival and reproduction of D. magna during 15 days of culture were shown in Figure 4. The survival of $D$. manga exposed with $O$. perornata decreased with the increase of the density of $O$. perornata in the culture. Significant differences in life history responses were observed for $D$. mangna exposed to $O$. perornata. Exposure to $O$. perornata at concentration of $20 \times 10^{3} \mathrm{cell} / \mathrm{mL}, 50 \times 10^{3}$ cell $/ \mathrm{mL}$, and $100 \times 10^{3}$ cell $/ \mathrm{mL}$ caused $33 \%$, 48 and $54 \%$ reduction of survival, respectively, on Day 15 (Fig. 4).

The maturity age and the number of offspring per female of $D$. magna cocultured with different densities of $O$. perornata are shown in the figure 4 . The growth of $D$. magna determined by the time to first reproduction was retarded by the presence of $O$. perornata (Fig. 5a) and the reproduction determined by the number offspring per female was inhibited by the presence of $O$. perornata in a dose-dependent manner (Fig. 5b). As shown in the survival curve above, many parent daphnids in the exposure treatments died before the first reproduction. 


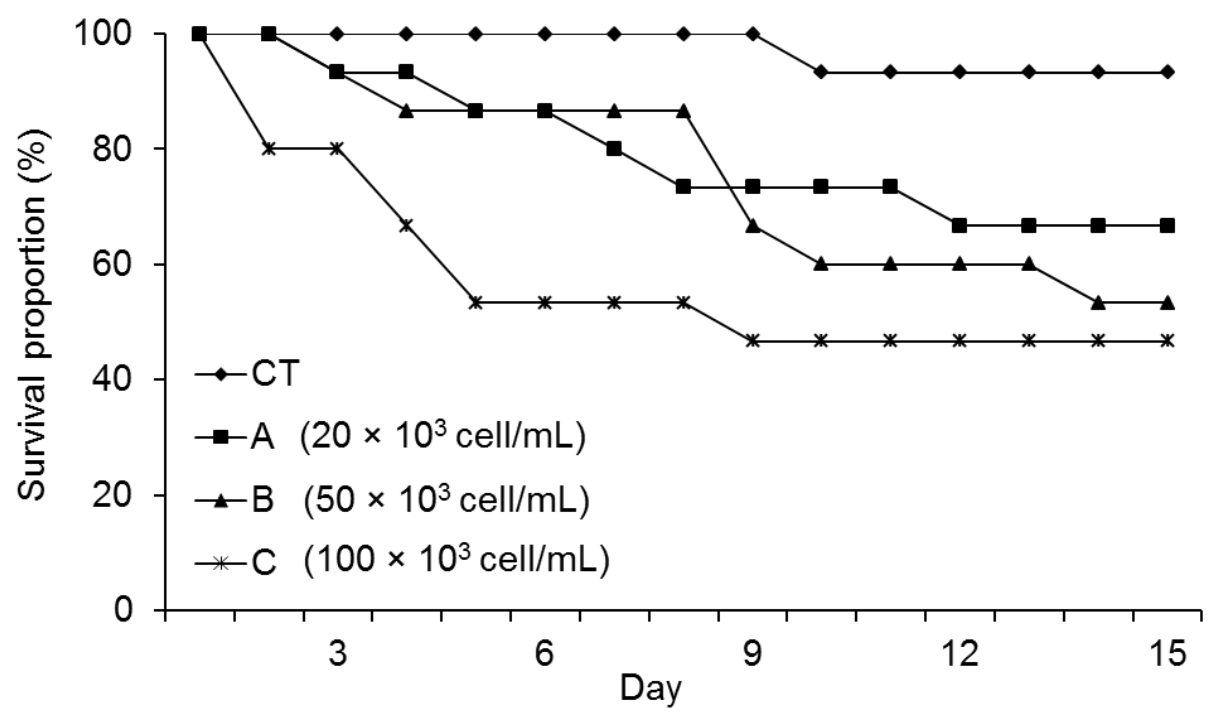

Figure 4. Chronic effects of $O$. perornata on the survival of D. magna Note: CT: contained only ISO medium.
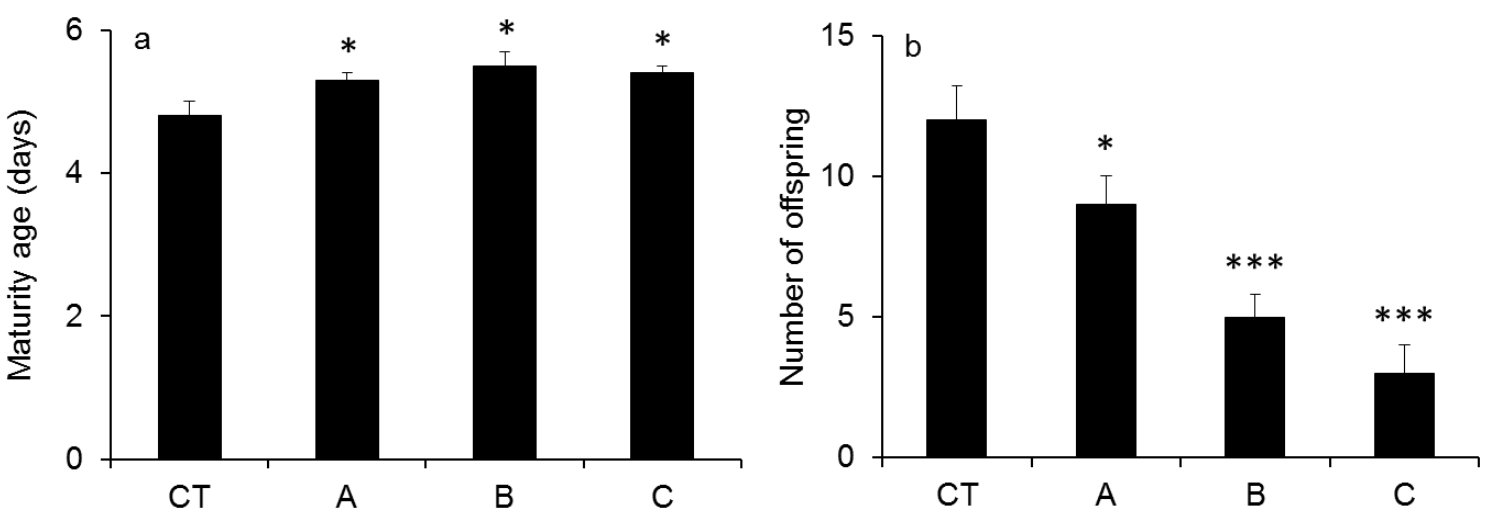

Figure 5. Maturity age (a) and number of offspring per female (b) of D. magna during exposure to different density of $O$. perornata. CT: control (contained only ISO medium); A: $20 \times 10^{3}$ cell $/ \mathrm{mL}$; B: $50 \times 10^{3} \mathrm{cell} / \mathrm{mL}$; and C: $100 \times 10^{3} \mathrm{cell} / \mathrm{mL}$

Many cyanobacteria species are harmful to freshwater herbivorous grazers such as Daphnia (Kuster \& Von-Eler, 2013). Colonial or filamentous cyanobacteria can mechanically interfere with Daphnia's filtering apparatus (Shams et al., 2014). Most of cyanobacteria lack essential sterols and sufficient amounts of polyunsaturated fatty acids and therefore cyanobacteria are a nutritionally inadequate food source for cladocerans (MartinCreuzburg, 2008). In addition, the production of some toxic secondary metabolisms may significantly reduce the fitness of Daphnia
(Lürling \& Vander, 2003). Oberhaus et al. (2007) reported that Daphnia could be grazing on filamentous cyanobateria Planktothrix rubescens, but they prefer to graze only small filaments. In the present study, population growth rates of D. magna fed with different concentration of $O$. perornata were reduced in the dosedependent manner. The negative effects of $O$. perornata on the survival and reproduction of D. magna may reflect the interference of the filtering apparatus of D. magna and an inadequate food source of $O$. perornata. 
Previous studies showed that filamentous cyanobacteria have a negative effect on Daphnia because of the interference of filaments with grazing on other available food sources (Kurmayer \& Jüttner, 1999; Shams et al., 2014). In addition, besides the toxic microcystins, a large number of bioactive oligopeptides have been identified and reported from Planktothrix (Oscillatoria) that show the inhibitory effects on serine proteases or other bioactive potential in animal cells (Kurmayer et al., 2016). These bioactive secondary metabolites could contribute to the overall toxic effects. Similarly, Smutná et al. (2014) reported that, when Daphnia were exposed to different toxic and non-toxic biomass of cyanobacteria, both toxic and nontoxic biomass conferred toxic effects on the tested animals, but the effects observed in the acute and chronic assays were independent of the samples' microcystin contents. They pointed out the importance of cyanobacterial components other than microcystins, such as lipopolysaccharides, various peptides and depsipeptides, polar alkaloid metabolites or other unidentified metabolites in the overall ecotoxicity of cyanobacterial biomass. Results of the present study are consistent with previous observations that non-microcystin bioactive secondary metabolites in filamentous cyanobacteria Oscillatoria may contribute significantly to the toxic effects on Daphnia. It is strongly recommended further investigations to elucidate non-microcystin bioactive compounds in Oscillatoria.

\section{CONCLUSION}

Results of the present study indicated that the species $O$. perornata isolated from the Tri An Reservoir were non-toxic strains. However, the living biomass of the non-toxic $O$. perornata caused significantly chronic toxic effects on D. magna. Higher densities have generated greater toxic effects on the test animals, suggesting that other second metabolites than cyanotoxins are likely to be responsible for the adverse effects. The mechanisms of toxicity of these unknown compounds remains to be determined. Other toxic and unknown compounds must be taken into account when investigating the toxic effects of cyanobacteria.

Acknowledgements: This research was funded by the International Foundation for Science (IFS) under grant number I-2-A6054-1.

\section{REFERENCES}

Brittain S., Mohamed Z. A., Wang J., Lehmann V. K. B., Carmichael W. W., Rinehart K. L., 2000. Isolation and characterization of microcystins from a River Nile strain of Oscillatoria tenuis Agardh ex Gomont. Toxicon, 38(12): 1759-1771.

Chorus I., Bartram J., 1999. Toxic cyanobacteria in water: A guide to their public health consequences, monitoring and management, Published on behalf of WHO, Spon Press, London.

Dao T. S., Cronberg G., Nimptsch J., DoHong L. -C., Wiegand C., 2010. Toxic cyanobacteria from Tri An Reservoir, Vietnam. Nova Hedwigia, 90(3-4): 433448.

Dao T. S., Tran P. T., Nguyen T. T. L., Nguyen T. S., Bui B. T., 2016. First report on toxicity of the cyanobacterium Planktothrix rubescens isolated from a fish pond in Soc Trang province. Journal of Biology, 38(1): 115-123. (in Vietnamese with English summary).

Dang Dinh Kim, Duong Thi Thuy, Nguyen Thi Thu Lien, Dao Thanh Son, Le Thi Phuong Quynh, Do Hong Lan Chi, 2014. Toxic cyanobateria in freshwater. Publishing House of Natural Science and Technology, 325 pp. (in Vietnamese).

Desikachary T. V., 1959. Cyanophyta. Indian council of agriculture research, New Delhi.

Duong T. T., Jähnichen S., Le T., Ho C., Hoang T., Nguyen T., Vu T., Dang, D. K., 2014. The occurrence of cyanobacteria and microcystins in the Hoan Kiem Lake and the Nui Coc reservoir (North Vietnam). Environ. Earth Sci., 71(5): 2419-2427. 
Ferrão-Filho A. D. S., Kozlowsky-Suzuki B., 2011. Cyanotoxins: Bioaccumulation and effects on aquatic animals. Mar. Drugs, 9(12): 2729-2772.

Ferrão-Filho A. D. S., Soares M. C. S., Magalhães D. F. V., Azevedo S. M. F. O., 2009. Biomonitoring of cyanotoxins in two tropical reservoirs by cladoceran toxicity bioassays. Ecotoxicol. Environ. Saf., 72(2): 479-489.

Figueiredo D. R., Azeiteiro U. M., Esteves S. M., Goncalves F. J., Pereira M. J., 2004. Microcystin-producing blooms - a serious global public health issue. Ecotoxicol. Environ. Saf., 59(2): 151-163.

Harke M. J., Steffen M. M., Gobler C. J., Otten T. G., Wilhelm S. W., Wood S. A., Paerl H. W., 2016. A review of the global ecology, genomics, and biogeography of the toxic cyanobacterium, Microcystis spp. Harmful Algae, 54: 4-20.

Herrera N. A., Echeverri L.F., Ferrão-Filho A. S., 2015. Effects of phytoplankton extracts containing the toxin microcystin-LR on the survival and reproduction of cladocerans. Toxicon, 95: 38-45.

Hisbergues M., Christiansen G., Rouhiainen L., Sivonen K., Börner T., 2003. PCRbased identification of microcystinproducing genotypes of different cyanobacterial genera. Arch. Microbiol., 180(6): 402-410.

Kardinaal W. E. A., Janse I., Agterveld M. K. V., Meima M., Snoek J., Mur L. R., Huisman J., Zwart G., Visser P. M., 2007. Microcystis genotype succession in relation to microcystin concentrations in freshwater lakes. Aquat. Microb. Ecol., 48(1): 1-12.

Kurmayer R., Juttner F., 1999. Strategies for the co-existence of zooplankton with the toxic cyanobacterium Planktothrix rubescens in Lake Zurich. J. Plankton Res., 21: 659-683.

Kurmayer R., Deng L., Entfellner E., 2016. Role of toxic and bioactive secondary metabolites in colonization and bloom formation by filamentous cyanobacteria Planktothrix. Harmful Algae, 54: 69-86.

Kuster C. J., Von-Eler E., 2013. Interspecific differences between D. pulex and D. magna in tolerance to cyanobacteria with protease inhibitors. PLoS One, 8(5): e62658.

Luu T. T. N., Nguyen T. T., 2008. Planktonic cyanobacteria species composition and seasonal change in $\mathrm{La}$ $\mathrm{Nga}$ river. Journal of Science and Development, 11(07). (in Vietnamese).

Lürling M., Vander G. E., 2003. Life-history characteristics of Daphnia exposed to dissolved microcystin-LR and to the cyanobacterium Microcystis aeruginosa with and without microcystins. Environ. Toxicol. Chem., 22: 1281-1287.

Martin-Creuzburg D., Von-Elert E., Hoffmann K. H., 2008. Nutritional constraints at the cyanobacteria-Daphnia magna interface: The role of sterols. Limnol. Oceanogr., 53: 456-468.

Nguyen L. T. T., Cronberg G., Larsen J., Moestrup Ø., 2007. Planktic cyanobacteria from freshwater localities in Thua Thien-Hue Province, Vietnam I. Morphology and distribution. Nova Hedwigia, 85: 1-34.

Oberhaus L., Gélinas M., Pinel-Alloul B., Ghadouani A., Humbert J. F., 2007. Grazing of two toxic Planktothrix species by Daphnia pulicaria: potential for bloom control and transfer of microcystins. $J$. Plankton Res., 29(10): 827-838.

OECD, 2012. OECD guideline for the testing of chemicals, number 2011, Daphnia magna Reproduction Test.

Pham T. L., Dang T. N., 2019. Microcystins in freshwater ecosystems: Occurrence, distribution, and current treatment approaches, in Water and wastewater treatment technologies, edited by Bui X. T., Chiemchaisri C., Fujioka T., Varjani S. pp. 15-36, Springer Singapore, Singapore. 
Pham T. L., Utsumi M., 2018. An overview of the accumulation of microcystins in aquatic ecosystems. J. Environ. Manage., 213: 520-529.

Pham T. L., Dao T. S., Tran N. D., Nimptsch J., Wiegand C., Motoo U., 2017. Influence of environmental factors on cyanobacterial biomass and microcystin concentration in the Dau Tieng Reservoir, a tropical eutrophic water body in Vietnam. Ann. Limnol-Int. J. Lim., 53: 89-100.

Pham T. L., Dao T. S., Shimizu K., Lan-Chi D. H., Utsumi M., 2015. Isolation and characterization of microcystinproducing cyanobacteria from Dau Tieng Reservoir, Vietnam. Nova Hedwigia, 101(1-2): 3-20.

Pineda-Mendoza R. M., Olvera-Ramírez R., Martínez-Jerónimo F., 2012. Microcystins produced by filamentous cyanobacteria in urban lakes. A case study in Mexico City. Hidrobiológica, 22(3): 290-298.
Shams S., Cerasino L., Salmaso N., Dietrich D. R., 2014. Experimental models of microcystin accumulation in Daphnia magna grazing on Planktothrix rubescens: Implications for water management. Aquat. Toxicol., 148 (Supplement C): 9-15.

Sivonen K., 1990. Effects of light, temperature, nitrate, orthophosphate, and bacteria on growth of and hepatotoxin production by Oscillatoria agardhii strains. Apply. Environ. Microbiol., 56: 2658-2666.

Smutná M., Babica P., Jarque S., Hilscherová K., Maršálek B., Haeba M., Bláha L., 2014. Acute, chronic and reproductive toxicity of complex cyanobacterial blooms in Daphnia magna and the role of microcystins. Toxicon, 79(0): 11-18.

Urbach E., Robertson D. L., Chisholm S. W., 1992. Multiple evolutionary origins of prochlorophytes within the cyanobacterial radiation. Nature, 355(6357): 267-270. 